\title{
The Cox Report and the US-China Arms Control Technical Exchange Program
}

\author{
M. S. Di Capua
}

September 1, 1999

U.S. Department of Energy

Lawrence

Livermore

National

Laboratory

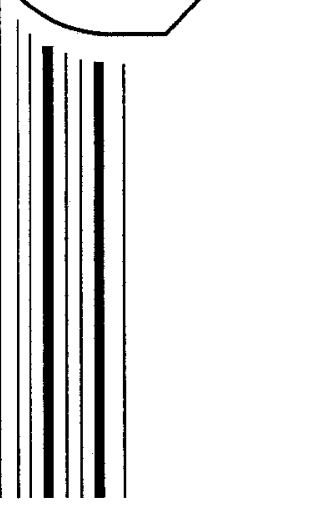




\section{DISCLAIMER}

This document was prepared as an account of work sponsored by an agency of the United States Government. Neither the United States Government nor the University of California nor any of their employees, makes any warranty, express or implied, or assumes any legal liability or responsibility for the accuracy, completeness, or usefulness of any information, apparatus, product, or process disclosed, or represents that its use would not infringe privately owned rights. Reference herein to any specific commercial product, process, or service by trade name, trademark, manufacturer, or otherwise, does not necessarily constitute or imply its endorsement, recommendation, or favoring by the United States Government or the University of California. The views and opinions of authors expressed herein do not necessarily state or reflect those of the United States Government or the University of California, and shall not be used for advertising or product endorsement purposes.

This is a preprint of a paper intended for publication in a journal or proceedings. Since changes may be made before publication, this preprint is made available with the understanding that it will not be cited or reproduced without the permission of the author.

This work was performed under the auspices of the United States Department of Energy by the University of California, Lawrence Livermore National Laboratory under contract No. W-7405-Eng-48.

This report has been reproduced directly from the best available copy.

Available electronically at http://www.doc.gov/bridge

Available for a processing fee to U.S. Department of Energy

And its contractors in paper from

U.S. Department of Energy

Office of Scientific and Technical Information

P.O. Box 62

Oak Ridge, TN 37831-0062

Telephone: (865) 576-8401

Facsimile: (865) 576-5728

E-mail: reports@adonis.osti.gov

Available for the sale to the public from

U.S. Department of Commerce

National Technical Information Service

5285 Port Royal Road

Springfield, VA 22161

Telephone: (800) 553-6847

Facsimile: (703) 605-6900

E-mail: orders@ntis.fedworld.gov

Online ordering: http://www.ntis.gov/ordering.htm

\section{OR}

Lawrence Livermore National Laboratory

Technical Information Department's Digital Library

http://www.llnl.gov/tid/Library.html 


\title{
The Cox Report and the US - China Arms Control Technical Exchange Program
}

\author{
by \\ Marco S. Di Capua \\ Proliferation Prevention and Arms Control Program \\ Lawrence Livermore National Laboratory \\ Livermore, CA 94550
}

The report issued by the Select Committee on US National Security and Military / Commercial Concerns with the People's Republic of China chaired by Representative Christopher Cox (Cox Report) ${ }^{1}$ : devotes attention in Volume 1 to interactions ${ }^{2}$ between the three US Department of Energy National laboratories ${ }^{3}$. and the China Academy of Engineering Physics (CAEP). ${ }^{4}$ These three US national laboratories, CAEP, and the Northwest Institute of Nuclear Technology (NINT) in China are responsible for research, development and testing of nuclear weapons.

The Cox report alleges that ${ }^{5}$

The China Academy of Engineering Physics has pursued a very close relationship with U.S. national weapons laboratories sending scientists as well as senior management to Los Alamos and Lawrence Livermore Members of the Academy of Engineering Physics senior management have made at least two trips during the mid-to-late nineties to U.S. national weapons laboratories to acquire information and collect intelligence. The presence of such PRC nationals at the U.S. national weapons laboratories facilitates the PRC targeting of U.S. weapons scientists for the purpose of obtaining nuclear weapons information.

\footnotetext{
${ }^{1}$ Report of the Select Committee on U.S. National Security and Military / Commercial Concerns with the People's Republic of China, Report 105-851, USGPO, Washington, DC (1999) hereafter referred to as "The Cox Report"

${ }^{2}$ The Cox Report discusses these interactions in Volume 1, Chapter 2, pp. 80-83

${ }^{3}$ The three US-DOE laboratories are: Lawrence Livermore National Laboratory, Livermore, CA (LLNL) managed by the University of California; Los Alamos National Laboratory, Los Alamos, NM (LANL), also managed by the University of California, Sandia National Laboratory, Albuquerque, NM (SNL) and Livermore, $\mathrm{CA}$, both managed by the Lockheed Martin Corporation.

${ }^{4}$ The China Academy of Engineering Physics, (previously known as the 9th Academy) under the Commission of Science Technology and Industry for the National Defense (COSTIND) is the People's Republic of China (PRC) organization responsible for China's nuclear weapons. An additional organization in China, the Northwest Institute of Nuclear Technology (NINT)in Xi'an, China, also under COSTIND was responsible for China's nuclear testing program. The history of these organizations is outlined in: China Builds the Bomb, John Lewis and Litai Xue, Stanford University press, Stanford, CA (1988)

${ }^{5}$ The Cox Report, p. 81 and ff.
} 
U.S. and PRC lab-to-lab exchanges were ended in the late 1980 's but were resumed in 1993. Scientific exchanges continue in many areas including high energy physics. Discussions at the U.S. national laboratories are supposed to be strictly limited to technical arms control and materials accounting issues. Nonetheless these visits and scientific conferences provide opportunities for the PRC to interact with U.S. scientists outside of official meetings, and facilitate the targeting of U.S. weapons scientists.

The U.S. national laboratories argue that there are reciprocal gains from the exchanges. The Department of Energy describes some of the insights gained from these exchanges as unique. On the other hand the PRC scientists have misled the U.S. about their objectives and technological developments. Despite considerable debate in Congress and the Executive branch, including several critical Government Accounting Office reports, the U.S. Government has never made a definite assessment of the risks versus benefits of scientific exchanges and foreign visitor programs involving the U.S national weapons laboratories.

Thus, the Cox report alleges that the "lab-to-lab" exchanges of the early 90's, were a pipeline for transfer of U.S. secret information about nuclear weapons to China.

This transfer is a risk that all the US Government policy makers and national laboratory scientists who conceived and established the exchange programs, the management of the national laboratories that hosted them, and the technical personnel who implemented them, recognized at the very beginning of the "lab-to-lab" exchange program. All took abinitio, decisive actions to mitigate and manage this risk. This paper describes the risk management and risk mitigating process at LLNL in some detail. The Cox Committee report does not discuss this process at all.

These laboratory-to-laboratory exchange programs were conceived and existed within the context of national and global security. Thus, this paper also describes the US national security, global security and foreign policy context of these "lab-to-lab" exchanges. The Cox report does not discuss this context either.

\section{The Foreign Policy Context for Interactions between US and Chinese Nuclear Weapons Laboratories}

With the cessation of nuclear testing and the signing (by the US and China among others), of the Comprehensive Test Ban Treaty (CTBT) in 1996 the US national laboratories are placing additional emphasis on technical matters and issues related to non-proliferation, arms control and treaty verification. These activities accelerated in the early 90's with the end of the nuclear arms race, the end of the Cold War and reductions in nuclear arsenals. For example, the US national laboratories began collaborating in the early 90 's with Russia on securing stockpiles of weapons grade plutonium through the Material Protection Control and Accountability Program; and, the Initiative for Proliferation Prevention (IPP) Program and the International Science and Technology Center (ISTV) that provides incentives for displaced nuclear weapons scientists to remain in Russia and the Community of Independent States. 
Non-proliferation and arms control activities are even taking place with a country the US is still in a state of hostilities with: ${ }^{6}$ the Democratic People's Republic of Korea (North Korea), where US national laboratory scientists are securing irradiated nuclear fuel in the nuclear facility in Nongbyon. This work falls under the US - DPRK Framework Agreement that freezes the DPRK program for production of fissile materials for nuclear weapons in exchange for nuclear power reactors supplied by the Korean Energy Development Organization (KEDO).

National laboratory scientists also train International Atomic Energy Agency (IAEA) inspectors and technical personnel who monitor compliance of third countries with the Nuclear Non-Proliferation (NPT) treaty. These inspectors come from IAEA member countries, including the People's Republic of China.

The US and China (which is also a recognized nuclear weapons state) established the US - China Arms Control Technical Exchange Program (ACE) in 1994 within the context of international activities, promoted mainly by the US Government, that pivot around nuclear non-proliferation, arms control, and negotiation and verification of nuclear arms related treaties. The Cox report applies the "laboratory-to-laboratory interactions" or "lab-to-lab exchanges" generic labels to the ACE program.

It also applies the same labels to interactions ${ }^{7}$ that took place between the US and China nuclear weapons organizations in the decade of the 80's following the reform and opening policies implemented under Deng Xiaoping's leadership. At that time China revealed some of its nuclear accomplishments with the publication of a comprehensive review ${ }^{8}$ of China's nuclear activities since the foundation of the PRC in 1949. More detailed records of the program began to appear in US publications in the late 80 's as well. ${ }^{9}$ These contacts had no specific focus other than to increase the US knowledge about a program that was not as well known or documented as the US program was.

Through these scientists' contacts and publications, which took place at the height of the Cold War when the strategic interests of the US and China were aligned against Russia, the US developed a technical understanding of the status and key players of China's nuclear weapons program. These contacts also occurred as key Chinese weapons scientists who trained in the US, UK, France and Germany between 1930 and 1950 were turning over the leadership of the program to a second generation of scientists that were trained in China and Russia. This second generation was unknown in the US at that time.

\footnotetext{
${ }^{6}$ The UN and the DPRK signed an armistice in July of 1953 but the DPRK demands that a U.S. - DPRK peace agreement replace the armistice.

${ }^{7}$ See for example: Broad, W., Spies vs. Sweat: The Debate Over China's Nuclear Advance, New York Times, 7 September 1999

${ }^{8}$ Li Jue et al: Dangdai Zhongguo de he gongye (China's Contemporary Nuclear Industry), Beijing, China (1987)

${ }^{9}$ China Builds the Bomb, John Lewis and Litai Xue, Stanford University Press, Stanford, CA (1988)
} 
The Cox Report correctly states that these contacts ended in the late $80^{\prime} \mathrm{s}^{10}$

\section{National Security -- An Anchor and Foundation of the US - China Arms Control Technical Exchange Program}

The anchor and foundation of the ACE program, from its very beginning as a US government initiative in 1994, are US national security interests. According to the State Department, the premise under which the ACE program was established is that US foreign policy and non proliferation interests could be positively served by increased labto lab contacts with the People's Republic of China in certain defined areas such as arms control verification and non-proliferation.

The view of the State Department was that the US should pursue contacts on an ad-hoc, exploratory basis ${ }^{11} \ldots$ in a manner that neither violates U.S. sanctions on China nor undercuts foreign policy or national security constraints on cooperation with China. In the view of the State Department, such contacts should not create public misapprehensions that the US is providing support to the Chinese nuclear weapons effort.

On this basis, the State Department granted permission to the US national laboratories for technical activities with CAEP, under the guidance of an Interagency Contact Group, in arms control treaty verification, nuclear safeguards and other proliferation topics. The State Department chaired the Interagency Contact Group but left it to DOE to supervise and fund the effort with funds for non-proliferation activities appropriated by Congress.

From the very start the US and China agreed that each would pay for its own activities and thus no moneys would be exchanged. In this regard the ACE program was fundamentally different than the lab-to-lab programs that were taking place in Russia at the same time.

The "ad-hoc" basis meant that both sides would carry out technical activities using a "bottoms-up" approach. ${ }^{12}$ An Interagency Contact Group consisting of the State Department, DOE, the US Arms Control and Disarmament Agency (now a part of the US Department of State), the US Department of Defense, and the White House through the National Security Council (NSC) and the White House Office of Science and Technology Policy (OSTP). The DOE provided policy guidance and approved in advance the technical activities proposed by scientists at the national laboratories. It remained up

\footnotetext{
${ }^{10}$ They actually ended in the wake of the Tiananmen Square events of June 1989.

${ }^{11}$ The absence of a "government-to-government" agreement between the US and the PRC determines the "ad-hoc" nature of the program.

${ }^{12}$ In this approach, research themes and activities rise up through successive later of management and administration that vets them.
} 
to the scientists themselves, who organized the effort through a US Steering Committee, to identify activities that could be acceptable to government agencies and officials on both sides.

The Steering Committee has one member from each laboratory. The Steering Committee meets regularly to: keep the program on track, keep the Interagency Contact Group informed, and coordinate technical activities at the three laboratories.

The laboratories provided visible and proactive counterintelligence (CI) supervision from separate budgets. This (CI) supervision has been a firm anchor throughout the program. The next section elaborates some of the details at LLNL.

Notwithstanding the broad technical scope of the ACE program, the size of the program remains small. At its peak, ACE funding supported the equivalent of two full time scientists per year at each laboratory. Supervision at DOE headquarters probably involved one tenth to one fifth of a full time DOE official per year depending on the amount of coordination required by the Interagency Contact Group.

\section{Risk Management in the ACE Program}

From the very start of the ACE program, the Interagency Contact Group, the Department of Energy, the Steering Committee, the National Laboratories, and the scientists themselves all realized that the $\mathrm{ACE}$ program and the participants were vulnerable. One vulnerability was scientists' access to nuclear and national security information that the US and the PRC must protect. Political vulnerability is another one, inasmuch as technical interactions in the ACE take place in subjects that involve issues of national security, are close to the policy making process, and very sensitive to domestic US politics. Thus the US devoted as much attention to management of the risks to national security that accompanied $\mathrm{ACE}$ as it did to the execution of the technical activities of the program.

The perceived risks of the program are:

1. That the ACE program could provide a setting for espionage,

2. That transfer of technologies and know-how could take place in contravention of US export control laws and regulations,

3. That technical interactions could take place in subjects, or at a time, where competing interests within the US Government had not yet been reconciled and the policy making process had not reached a consensus,

4. That un-approved technical interactions could muddle or confuse ongoing US /

China bilateral or multilateral negotiations,

5. That mishaps, real or perceived, in any of these areas could be fatal to the program or the careers of the scientists involved, 
6. That actual or perceived security missteps could result in accusations of espionage for the participants,

7. That ACE activities could provide opportunities to CAEP so it could pinpoint technologies and experts for targeting.

To manage these risks ab-initio in the US, the organizers built four shells around the ACE program, common to all three laboratories, in addition to the multilevel security approach which relies on control of access and need to know at National laboratory facilities.

In the multilevel security approach, the laboratories have fenced, controlled access "kernels" called limited or exclusion areas where classified activities take place. These limited or exclusion areas have enhanced physical security, and security clearances and need-to-know are required for access. Chinese visitors were not allowed into these areas with the exception of the Director's office for protocol reasons.

These "kernels" are surrounded by areas where unclassified activities take place or that may house valuable equipment. These "business" areas, which are not accessible to the general public, do not require a clearance, but are still subject to visitor control. Access is not much different from areas where corporations conduct their business. In these areas visitors need to carry badges that authorize their presence and may require escorts in addition. Finally, there are some areas open to the general public such as cafeterias, auditoria, visitor's centers etc. Chinese visitors where allowed in selected facilities in the "business" areas and in open areas as well.

The additional shells are:

1. The Interagency Contact Group,

2. The US Steering Committee

3. Integral counterintelligence oversight at the laboratories

4. Embassy and Consular oversight in China

The Interagency Contact Group provides guidance on what may be appropriate subjects for interactions proposed by the US and Chinese scientists. The Interagency group in 1995 approved nuclear materials protection, control and accounting, atmospheric science related to non-proliferation, monitoring technologies for nuclear materials and processes and their application, and technical issues related to monitoring of a CTBT. It later added control of nuclear technologies (export controls).

These collaboration subjects remained unchanged from the inception of the ACE program until its suspension in the wake of the Cox Committee report allegations.

The US Steering Committee rotates the chairmanship among the three laboratories. The Steering Committee guarantees that the three laboratories speak with one voice (the 
Chairman's) in their interactions with China and the CAEP. The Committee briefs and takes guidance from the Interagency. The Committee develops the work plans for the $\mathrm{ACE}$ program and distributes $\mathrm{ACE}$ tasks among the three laboratories to meet program and budget milestones.

The Steering Committee also undertakes a security control role, by supervising the ACE program, the participants and the technical activities.

Counterintelligence (CI) has been an integral part of the ACE program from the program conception. The ACE program has incorporated constant counterintelligence (CI) oversight since. CI oversight is an additional layer of protection over and above the multilevel security approach at the national laboratories outlined above.

At LLNL, for example, CI provides protection to the ACE program through: background checks on $\mathrm{ACE}$ visitors from China, $\mathrm{CI}$ advice on how to safeguard sensitive information from elicitation, cautionary briefings based on the experience of previous visitors or travelers, in-person briefings before travel, and debriefings upon return. In addition ACE delegations traveling to China bring their own interpreters, travel as a group, make their own hotel arrangements and use the English language (even those who speak standard Chinese or other languages). Through visit and travel post-mortems $\mathrm{CI}$, on occasion has identified areas that required additional or different security attention. SNL and LANL have similar programs.

The Beijing US Embassy oversight is an integral part of ACE visits to China. A Request for Country Clearance advises the Embassy in advance about activities the ACE program will undertake in visits to China. The Embassy grants approval for the visits at the discretion of the Ambassador. In Embassy premises, Embassy officials provide the ACE travelers insights on China politics that may have an impact on the ACE program. Conversely, through these Embassy interactions, the ACE delegations share their insights and observations with the foreign policy establishment. State Department cables reporting the accomplishment of the visit were routinely drafted at the Embassy in Beijing for a wide Washington distribution.

\section{Contributions of the US China Arms Control Technical Exchange Program to US National Security}

An intellectually honest approach to nuclear matters in China must begin with the premises that:

China has the intellectual resources to develop nuclear weapons to meet its deterrence needs,

China has the industrial infrastructure to produce nuclear weapons, 
China's nuclear weapons program shares the same intellectual ancestors as the US program, namely the giants of physics in European universities of the 1930's and the US universities of the 40 's, ${ }^{13}$

China's program also shares ancestry with the Russian program of the 50 's, ${ }^{14}$

China has nuclear weapons in its arsenal

China has been a nuclear weapons state for 35 years

What distinguishes China from the other weapons states (Russia, Britain, France and the US) is that after the Sino-Soviet rift of 1960 , China entered a period of isolation at a time when vigorous scientific and arms control interactions regarding nuclear weapons were taking place, even among cold war foes. In a 40 year-long arms control process US and USSR weapons scientists participated in the successful negotiation of the Limited Test Ban Treaty (1963), the (Nuclear) Non-Proliferation Treaty (NPT, 1968), the AntiBallistic Missile Treaty (1972), the Anti Ballistic Missile Protocol (1974) and the Threshold Test Ban Treaty (1974) ${ }^{15}$.

China's experience with arms control and non-proliferation international activities, in comparison, is much shorter. China joined the IAEA in 1983 and signed the NPT in 1992. The CTBT (signed in 1996) is the first nuclear arms control treaty that China actively negotiated. When the ACE program started, China was the wild card in the CTBT negotiations. A CTBT had become a priority for the US. Russia, having lost access to its test site in Semipalatinsk, Kazakhstan, had limited options. Britain favored it, and it was clear that a blend of international pressure and incentives could get France to come on board.

Simultaneously, the US had concerns that Chinese nuclear entities may be supplying nuclear technology and materials to the Pakistan un-safeguarded program, despite China's professed adherence to the non-proliferation treaty starting in 1992.

To address the technical component of these treaty verification, non proliferation and arms control issues that had a direct bearing on US national security, the US exploited a window of opportunity to construct the ACE program.

This window arose with a visit of the Los Alamos director and other scientists to China in late 1993 and a reciprocal visit, in February of 1994, of six PRC nuclear complex high ranking visitors to LANL, LLNL, and SNL.

\footnotetext{
${ }^{13}$ See biographical sketches in "China Makes the Bomb," J. Lewis and L. Xue, Stanford University Press (1989)

${ }^{14}$ For a candid first person account of Soviet and Chinese cooperation in nuclear weapons development see: Negin, Ye. A., and Smirnov, Yu. N., "Did the Soviet Union Share its Atomic Secrets with China?, "in: Proceedings of the International Symposium on Science and Society - The History of the Soviet Atomic Project, Atomic Science and Technology Publishing House (IZDAT), Moscow,(1997)

${ }^{15}$ See: Arms Control and Disarmament Agreements, United States Arms Control and Disarmament Agency, Washington, DC (1996), also USGPO ISBN 0-16-048689-0
} 
After this visit, an exchange of letters between the State Department (July 1994) and the DOE (October 1994) followed, setting the policy framework for interactions between US and China nuclear weapons laboratories that would become the US - China Arms Control Technical Exchange (ACE) Program.

Within this policy framework, the US Government sanctioned an initiative where the national laboratories would propose to CAEP a collaboration on nuclear materials protection, control and accounting, atmospheric science related to non-proliferation and treaty verification, monitoring technologies and their application for nuclear materials processing and storage, and technical means to monitor a CTBT. CAEP accepted this proposal and thus the ACE program was born. Workshops on export controls were added soon after the program began.

The ACE program has three important demonstration goals:

1. To show to the China Academy of Engineering Physics that developing and deploying technical expertise in nuclear materials management, nuclear arms treaty implementation and treaty verification is an important function of nuclear weapons laboratories;

2. That the US devotes significant national laboratory resources to arms control and non-proliferation activities in the national laboratories; and,

3. That nuclear weapons scientists, supporting policymakers, have a role in non-proliferation and arms control

A longer term goal, linked to arms control treaty verification, is to demonstrate that to foster trust and participation in international arms control and non-proliferation regimes, information had to be and could be shared with the international community without compromising national security. The US expected that the program would demonstrate how the US and Russia, for example, can share information about unclassified and nonsensitive aspects of their nuclear weapons programs without compromising national security.

It appears that as the program was starting interest in nuclear non-proliferation and arms control had already developed within the leadership of CAEP due to the ongoing CTBT negotiations in Geneva. This interest is witnessed in the publication of a book in 1996 on the scientific and technical foundations of arms control by Du Xiang Wan, a deputy director of the CAEP. ${ }^{16}$

\footnotetext{
${ }^{16} \mathrm{Du}$, Xiangwan, Kezhunbei kongzhe de kexue jishu jichu (The Scientific and Technical Foundations of Nuclear Arms Control) China Defense Industry Press, Beijing (1996). While this book reviews arms control abroad it provides no insights on China's technologies or attitudes on arms control. The book may very well been written as a reference compendium to bring the Chinese delegation to the Conference on Disarmament CTBT negotiations up to speed on nuclear arms control.
} 


\section{Technical Accomplishments of the ACE Program}

A significant accomplishment of the ACE program was the US-China Integrated Demonstration of Nuclear Materials Protection Control and Accountability (MPC\&A). It was dedicated on July 21, 1998 shortly following President Clinton's Beijing summit of June 1998.

The MPC\&A demonstration represented the first major bilateral nuclear initiative following the Beijing Summit. It exhibited the most important aspects of advanced nuclear materials safeguards systems and showcases working equipment and techniques to officials, nuclear material managers and technologists. The demonstration took place at the easily accessible Laboratory for Nuclear Safeguards of the China Institute of Atomic Energy (CIAE) located in the Fengshan district about forty-five kilometers southwest of Beijing.

A unique feature of this integrated demonstration was the publication of a bi-lingual (English and Chinese) primer on the technical aspects of nuclear materials protection, control and accountability. This Los Alamos report,. ${ }^{17}$ was co-authored by ACE scientists from the CAEP, LANL, LLNL and SNL. The US and Chinese laboratories expected that this would only be the first of a series of joint, bi-lingual publications on non-proliferation and arms control topics.

The program had other accomplishments as well. It has carried out workshops on export controls for CAEP scientists, atmospheric modeling, and monitoring and verification technologies. A paper by Prindle elaborates on these achievements in more detail. ${ }^{18}$

At this point, both sides were pleased by the momentum that the program had gathered and the confidence that the US and Chinese governments were expressing on the importance of the ACE program to the national security of both countries and the propriety with which technical tasks were carried out. In addition, the enthusiasm with which a younger generation of Chinese scientists were embracing up-to-date techniques for nuclear materials control and treaty verification bade well for the future of the ACE program.

Many of these activities took place in 1997 and 1998. At this time, coincidentally, China' leadership was carrying out an extensive restructuring of the military and civilian bureaucracies. These reforms accelerated after the election of Zhu Rongzhi as Premier in March of 1998 . These reforms also affected China civilian and nuclear military

\footnotetext{
${ }^{17}$ Chen, X., Di Capua, M., Hsu, W., Hsue, S., Prindle, N., Rodriguez, J., Sinkule, B., Wang, T., Integrated Demonstration of Materials Protection, Control and Accountability, LALP-98-65, June 1998

${ }_{18}$ Prindle, N. H. The US - China Lab-to-Lab Technical Exchange Program, The Nonproliferation Review

5 (Spring-Summer 1998), pp.111-118, MIIS, Monterey, CA (1998)
} 
organizations and are still having an impact on China's approach to non-proliferation and arms control. A paper by $\mathrm{Hsu}^{19}$ elaborates on these changes in detail.

Encouraged by these successes, the Joint US - China ACE Steering Committee, met in late 1998 to select activities the program could accomplish in the $21^{\text {st }}$ century. The steering committee identified opportunities to:

1. Carry out joint technical activities with the Northwest Institute of Nuclear Technologies (NINT) in Xi' an on seismic verification of the CTBT ${ }^{20}$

2. Apply one of the techniques that were implemented at the MPC\&A demonstration at a fuel fabrication plant in China. A preliminary schedule for this activity established at that meeting.

3.Hold preliminary discussions with CAEP on an CTBT on-site inspection table-top exercise.

4. Initiate discussions of techniques that may be applicable to verify a Fissile Materials Cut-Off Treaty (FMCT) regime.

At no time did any of these exchanges ever come close to discussing scientific information that could benefit China's nuclear weapons program.

In February of 1999, following the allegations of the Cox report, NINT told the US Steering Committee that the start of technical activities related to CTBT verification would have to wait for more propitious times. Similarly, CIAE gave notice that a visit that DOE nuclear material management officials were planning for the spring would be postponed as well. The most severe blow came when Ambassador Sha Zhukang, the Director of the Office of Non proliferation and Arms Control at the China Ministry of Foreign Affairs canceled participation at a traditional arms control meeting at Sandia National Laboratories in Albuquerque. Sha told his Sandia hosts that the presence of a Chinese official at a national laboratory would inflame passions further and would not further the interests of the US and China. Since then, other related nuclear activities have been canceled by China as well.

\section{Conclusions}

\footnotetext{
${ }^{19} \mathrm{Hsu}$, W. L., The Impact of Government Restructuring on Chinese Nuclear Policy Making, The NonProliferation Review, Fall 1999, MIIS, Monterey, CA (1999)

${ }^{20}$ NINT is the unit of COSTIND that carried out the Chinese nuclear test program. NINT was a very welcome addition to the ACE program.
} 
The ACE program furthered the national security interests of the US by promoting technical approaches to the implementation and verification of arms control treaties that the international community embraces.

The Cox Committee report suggests that uncontrolled interactions were taking place between US and Chinese nuclear weapons scientists in the course of the ACE program. On the contrary, elaborate controls were in place at the very beginning and remained in place to control the interactions and protect US national security information.

The ACE program payoff to national security was just beginning and its suspension, resulting from the Cox reports allegations, is a setback to US - China progress on arms control. 